\title{
ANALYSIS OF IMPLEMENTATION GOOD CORPORATE GOVERNANCE ON MOTIVATION AND PERFORMANCE OF RESOURCES PEOPLE IN THE PUTRA WASPADA HOSPITAL
}

\author{
Suhardi \\ STIKes Surya Mitra Husada Kediri \\ Email: hardies_berseri@yahoo.com
}

\begin{abstract}
Abstrak
Motivasi dan kinerja sumber daya manusia merupakan salah satu permasalahan kompleks suatu instansi pemerintah maupun swasta dalam melaksanakan loyalitas kerja. Hal tersebut, merupakan hambatan perusahaan dalam mencapai kemajuan. Permasalahan tersebut, berkaitan dengan lemahnya tatakelola dan sistem manajerial suatu perusahaan. Penelitian dilaksanakan pada tanggal 15-25 Juli 2017 yang bertujuan untuk menganalisis Implementasi Good Corporate Governance Terhadap Motivasi Dan Kinerja Sumber Daya Manusia di Rumah Sakit Putra Waspada. Desain penelitian yang digunakan Explanatory research cross sectional. Populasi seluruh SDM yang ada di Rumah Sakit Putra Waspada jumlah sampel 93 responden dengan menggunakan teknik simple Random Sampling. Pengolahan data dianalisis dengan uji statistik regresi logistic multivariat. Dari hasil uji statistik menunjukan bahwa ada analisis Implementasi Good Corporate Governance Terhadap Motivasi Dan Kinerja sumber daya manusia di Rumah Sakit Putra Waspada dengan nilai $\mathrm{P}_{\text {value }}=0,000$ dan $\alpha 0,05$ yang berarti $\mathrm{P}<0,05$. Perlu penerapan tatakelola Good Governance Corporate oleh manajerial untuk mewujudkan keterbukaan serta pengawasan dalam instansi perusahaan.
\end{abstract}

Kata kunci: Good Governance Corporate, Motivasi dan Kinerja.

\begin{abstract}
Motivation and performance of human resources is one of the complex problems of a government and private agencies in implementing work loyalty. This is a barrier to achieving progress. These problems, related to the weak governance and managerial system of a company. The research was conducted on 15-25 July 2017 which aims to analyze the Implementation of Good Corporate Governance on Motivation and Human Resource Performance in Putra Waspada Hospital. The research design used Explanatory research cross sectional. Population of all human resources in Putra Waspada Hospital amount of samples 93 respondents using simple Random Sampling technique. Data processing was analyzed by multivariate logistic regression statistic test. From the results of statistical tests show that there is analysis Implementation of Good Corporate Governance Against Motivation and Performance of human resources in Putra Waspada Hospital with value $P_{\text {value }}=0,000$ and $\alpha 0.05$ which means $P<0.05$. It is necessary to apply Good Governance Corporate Governance by managers to realize transparency and supervision in corporate institutions.
\end{abstract}

Keywords: Good Corporate Governance, Motivation and Performance. 
PRELIMINARY

In the era of globalization, demands an efficient and competent system of openness in terms of government, private sector and civil society, which has both public and personal services. No less important a hospital institution must also have competent managerial in terms of structural and quality services. Hospital is an important part of a health systems oriented to public health services. Hospital Service problematics is not only limited to health service problem. Internal hospital problems will also be an obstacle in carrying out the service as well as employee problems in implementing performance loyally.

Hospital is a labor intensive, capital intensive, and skill intensive organization (Soedarmono,S,dkk, 2013). According to WHO (2003), hospital is an institution as an integral part of health organization and social organization, whose function is to offer optimal health services, both curative and preventive, for outpatients and inpatients in the form of health service and health care.A hospital institution has components that are very important both material and non-material to support the implementation of health services. Components that very important is the role of a worker / employee is involved in an institute and companies. According to Hasibuan (2014), the employee is any person providing services (either in mind or in the form of labor) and get remuneration or compensation, which amount has been determined in advance. Each employee in a company are required to have potential to flourish prosecuted in order to improve motivation and performance. According to Hasibuan (2014) an employee is anyone who provides services (whether in the form of mind or in the form of personnel) and receives compensation or compensation whose amount has been determined in advance. Every employee in a company is required to have the potential to grow is demanded in order to improve motivation and performance. Motivation is the provision of the driving force to create an enthusiasm of one's work so that they will cooperate effectively and integrated with all efforts to achieve satisfaction (Hasibuan, 2014). According to Mahsun (2006) Performance is a description of the level of achievement of the implementation of an activity / program / policy in realizing organizational goals, objectives, mission and vision contained in the strategic planning of an organization.

One of the problems faced by corporate is the lack of good management. Similarly, corporate company that provides services in the field of Health (Hospital). In Indonesia, according to the company and industry from the 1451 implementation of good corporate governance system to the HR performance was accomplished $45 \%$. This number shows the lack of accounting standard and regulations, as well as wide power in corporate management causes inefficiency and it affects motivation and performance of employees.

Employee performance problem is a problem that is often faced by every company both private and government agencies. According to the World Health Organization (2015) estimates that 450 million employees working in health institutions around 35\% much decreased in giving services to patients. Figures from DISNAKER Indonesia (2008) shows that out of 1000 Employees there are 185 employees companies decreased performance loyalty. In the province of East Java (2012) it is estimated that there are $21 \%$ who experience a decrease in motivation in the work of 38 million employees of the company. Data from the Department of Labor Tulungagung (2012) 
indicates that from 1.002.113 employees of the company there are 4.026 employees experienced a decrease in performance, especially in the time discipline. From initial studies on can decrease the trust of human resources at the hospital Son Wary of corporate governance both involving components Transparency (Transparency), participation (Participation) and Justice (Fairness) in addition there is a decline in motivation and the performance of the human resources around $30 \%$ while the rate of attendance of employees while attending a meeting of about $40 \%$ weed out prospective employees who can attend the meeting.

As one of the efforts to overcome the weakness of many companies in Indonesia, the business people in Indonesia agree on the implementation of Good Corporate Governance (GCG). Implementation of Good Corporate Governance is intended to create information disclosure, the responsibility of the leadership, fair treatment for every employee in carrying out the obligations and receive his rights as an employee and the involvement of all employees in the development of an institution and company to become better.

As a concept, Good Corporate Governance can be used to measure the performance of certain employees with the principles of directing and controlling the organization to achieve a balance between strength and authority in providing accountability to stakeholders. The main principles of Good Corporate Governance are stated by Widilestariningtyas (2012).

\section{Formulation of the problem}

Analyzing Implementation of good corporate governance on the motivation and performance of employees at Putra Waspada Hospital

\section{Research purposes}

This study aims to clicking implementation of good corporate governance analysis restricted motivation and performance of Human Resources at Putra Waspada Hospital.

As an input to the development of science in the field of science and advance the research of management science which is the basis of further research on related topics.

\section{RESEARCH METHODS}

This research method is cross sectional explanatory research or study the explanation through a quantitative approach, the data collection techniques are through questionnaires and retrieval of documentation. This research emphasizes on the relationship between research variables by testing the hypothesis. Descriptions contain the description but the focus is on the relationship between variables (Singarimbun in Swasono, 2011). The population of this research are all nonhomogen and stratified employees of Putra Waspada Hospital, counted 120 persons with sample 93 persons. The sampling of this research is using proportional random sampling technique. The instruments used are questionnaires and observation sheets.

\section{RESEARCH RESULT}

\section{Characteristics of Respondents}

Table 1 characteristics respondents by age, gender, past education, position, length of service and HR.

\begin{tabular}{clcc}
\hline No & Characteristics & $\boldsymbol{\Sigma}$ & $\boldsymbol{\%}$ \\
\hline $\mathbf{1}$ & Age & 7 & 8 \\
& <20 years & 56 & 60 \\
& 20-30 years & 30 & 32 \\
& > 30 years & & \\
\hline $\mathbf{2}$ & Gender & 39 & 42 \\
& Man & 54 & 58 \\
& Women & & \\
\hline
\end{tabular}




\begin{tabular}{clcc}
\hline 3 & Last education & & \\
& SD & 0 & 0 \\
& SMP & 0 & 0 \\
& SMA & 37 & 40 \\
& PT & 56 & 60 \\
\hline $\mathbf{4}$ & Position & & \\
& Medical & 3 & 3 \\
& Support & 18 & 19 \\
& Paramedics & 42 & 43 \\
& Nonmedic & 30 & 53 \\
\hline $\mathbf{5}$ & Length of work & & \\
& <1 year & 4 & 4 \\
& 1-2 years & 15 & 16 \\
& 3-4 years & 44 & 48 \\
& > 4 years & 30 & 32 \\
\hline $\mathbf{6}$ & HR & & \\
& Training & 1 & 1 \\
& Contract & 46 & 50 \\
& Permanent & 46 & 49 \\
\hline
\end{tabular}

93 most of the respondents received a good transparency system as much as 50 respondents $(54 \%)$. The results of logistic regression analysis showed that $p$-Value $0.00<\alpha=0.05$ so that $\mathrm{H} 0$ rejected and $\mathrm{H} 1$ accepted which means no significant effect on the motivation of the application of the transparency system human resources in Putra Waspada hospital. Based on the results of cross tabulations, it is known that with the system Transparency well, nearly half of HR can have a good motivation with as many as 28 respondents $(30.1 \%)$.

There is a correspondence between existing theory and facts, the availability of adequate information and the openness between the policy givers in an agency can have a very positive impact on human resources.

Table 2 Characteristics of Variable

\begin{tabular}{|c|c|c|c|c|c|c|c|c|c|c|c|c|}
\hline \multirow{2}{*}{ Characteristic } & \multicolumn{2}{|c|}{ Transparency } & \multicolumn{2}{|c|}{ Participation } & \multicolumn{2}{|c|}{ Accountability } & \multicolumn{2}{|c|}{ Fairness } & \multicolumn{2}{|c|}{ Motivation } & \multicolumn{2}{|c|}{ Performance } \\
\hline & $\Sigma$ & $\%$ & $\Sigma$ & $\%$ & $\Sigma$ & $\%$ & $\Sigma$ & $\%$ & $\Sigma$ & $\%$ & $\Sigma$ & $\%$ \\
\hline Good & 40 & 43 & 50 & 54 & 42 & 45 & 49 & 53 & 49 & 53 & 53 & 57 \\
\hline Enough & 25 & 26 & 17 & 18 & 20 & 22 & 14 & 15 & 26 & 28 & 14 & 15 \\
\hline Less & 29 & 31 & 26 & 28 & 31 & 33 & 30 & 32 & 18 & 19 & 26 & 28 \\
\hline
\end{tabular}

From Table 2 that the respondents have good transparency as much as 40 respondents $(43 \%)$, respondents have good participation 50 respondents (54\%), respondents having Accountability well as much as 42 respondents (45\%), respondents have fairness good, a total of 49 respondents $(53 \%)$, respondents had Motivation good rate of 49 respondents (53\%), and respondents have a good performance, as many as 53 respondents $(57 \%)$.

\section{DISCUSSION}

Transparency influence on the motivation of Human Resources in Putra Waspada Hospital

Based on the results of data obtained during the study on June 15-21, 2017 known
In accordance with the existing facts, the human resources in Putra Hospital are wary of receiving the Transparency

system well, can have good motivation, so

as to increase the encouragement as well as give a positive impact in providing the best service to the community and the use of existing services.

\section{Participation influence on the motivation of Human Resources in Putra Waspada Hospital}

Based on the results of the research, it is known that from 93 most of the respondents had good participation as much as 50 respondents $(54 \%)$. The results of logistic regression analysis showed that $p$-Value $0.00<\alpha=0.05$ so that $\mathrm{H} 0$ rejected and $\mathrm{H} 1$ 
accepted which means no significant effect on the motivation of the application of the system participation of human resources in Putra Waspada hospital. Based on the results of cross-tabulation, it is known that almost half, human resources that can implement the Participation system well, have a working motivation as much as 23 respondents $(24.7 \%)$.

\section{Influence Motivation Accountability to Human Resources in Putra Waspada Hospital}

Based on the results of the study note that of 93 most of the respondents have good accountability as much as 50 respondents $(54 \%)$. The results of logistic regression analysis showed that $p$-Value $0.00<\alpha=0.05$ so that $\mathrm{H} 0$ rejected and $\mathrm{H} 1$ accepted which means no significant effect on the motivation of the application of the system Accountability human resources in Putra Waspada hospital. Based on cross tabulation is known that, that almost half of HR can implement Accountability system well, having a good motivation with as many as 28 respondents $(30.1 \%)$.

Fairness influence on the motivation of Human Resources in Putra Waspada Hospital

From the results of the study note that, 93 most of respondents have a good Fairness as many as 49 respondents (53\%). The results of logistic regression analysis showed that $p$-Value $0.00<\alpha=0.05$ so that $\mathrm{H} 0$ rejected and $\mathrm{H} 1$ accepted which means no significant effect on the application of the system fairness motivation of human resources at the Putra Waspada hospital.

Based on the results of cross tabulations known that, that nearly half, $\mathrm{HR}$ can receive fairness system well, has good motivation to work with as many as 27 respondents (29\%). This is supported by the theory of factors that affect motivation is with a fair pay system.Salary, the degree of reasonableness of salary received in return for his work.Fairness is expected to make all company assets managed properly and prudently (careful), so it appears the protection of shareholders' interests in a fair (fair and square).

Transparency influence on the performance of Human Resources in Putra Waspada Hospital

Based on the results of data obtained during the study on June 15-21, 2017 known 93 most of the respondents received a good transparency system as much as 50 respondents $(54 \%)$. The results of logistic regression analysis showed that $p$-Value $0.00<\alpha=0.05$ so that $\mathrm{H} 0$ rejected and $\mathrm{H} 1$ accepted which means no significant effect on the application of the system transparency human resource performance in Putra Waspada hospital. Based on the results of cross-tabulation, it is known that, almost half, human resources that can implement the Transparency system well, has a good performance as much as 25 respondents $(26.9 \%)$.

From the results of research, the existence of balance between theory and fact that there with the information can give a very good impact on the performance of human resources. It is also influenced by performance factors that is the existence of factor systems, such as work facilities will provide a very good impact for offering service in an agency.

\section{Participation Influence on Performance of Human Resources in Putra Waspada Hospital}

Based on the results of the research, it is known that from 93 most of the respondents had good participation as much as 50 respondents $(54 \%)$. The results of logistic 
regression analysis showed that $p$-Value $0.00<\alpha=0.05$ so that $\mathrm{H} 0$ rejected and $\mathrm{H} 1$ accepted which means no significant effect on the application of the system of participation of human resource performance in Putra Waspada hospital.

Based on the results of cross-tabulation, it is known that almost half, human resources that can implement the Participation System with Enough, have a good performance as much as 32 respondents (34.4\%). From the description, it can be drawn an understanding that participation is also often called participation or participation of the community, defined as the motivation and involvement of the community actively and organized in all stages of development, from the preparation stage, planning, implementation, maintenance, evaluation to development or expansion.

Effect of Performance Accountability to Human Resources in Putra Waspada Hospital

From the results of the study note that, 93 most of respondents have a good Fairness as many as 49 respondents (53\%). The results of logistic regression analysis showed that $p$-Value $0.00<\alpha=0.05$ so that $\mathrm{H} 0$ rejected and $\mathrm{H} 1$ accepted which means that there is a significant effect fairness application system on the performance of human resources at the Putra Waspada hospital.

Based on the results of cross-tabulation, it is known that almost half, human resources that can implement the system Accountability well, has a good performance as much as 25 respondents $(26.9 \%)$.

Fairness influence on the performance of Human Resources in Putra Waspada Hospital
From the results of the study note that, 93 most of respondents have a good Fairness as many as 49 respondents (53\%). The results of logistic regression analysis showed that $p$-Value $0.00<\alpha=0.05$ so that $\mathrm{H} 0$ rejected and $\mathrm{H} 1$ accepted which means no significant effect on the motivation of the application of the system fairness human resources at the Putra Waspada hospital. Based on the result of day tabulation result, it is known that most of respondents, human resources who can implement Fairness system well, have good performance as much 49 respondents $(52,7 \%)$.

\section{CONCLUSIONS AND SUGGESTION Conclusion}

There is a relationship between Analysis Implementation of Good Corporate Governance to the Motivation and Performance of Human Resources available at Putra Waspada Hospital

\section{Suggestion}

1. For Researchers

In this research can be used as a real experience in conducting research as well as a medium of learning to apply the knowledge gained in the lecture.

2. For Health Care Unit

It is expected that related institutions can apply the Good Corporate Governance system wisely and thoroughly and improve the quality of management so that it is expected to improve the whole system and improve the motivation and quality performance of human resources in the hospital.

3. For Respondents

Adding knowledge of existing human resources and expected to be able to improve the quality and existence of all Human Resources 
to carry out duties and responsibilities.

\section{BIBLIOGRAPHY}

Alimul, Hdayat, 2008. Metode Penelitian Keperawatan Dan Teknis Analisis Data, Salemba Medika, Jakarta, Indonesia.

Ambarwati, dkk. 2013, „Analisis Pengaruh Penerapan Prinsip-Prinsip Good Corporate Governance dan Komitmen Organisasi Terhadap Kinerja Aparatur Pemerintahan (Studi Empiris pada Instansi-Instandi dan Satuan Kerja Perangkat Daerah Kabupaten Banyumas), Tesis, Fakultas Ekonomi, Universitas Jendral Soedirman, Sumatra.

Andi, Nurwahida, 2012, „Hubungan Prinsip - Prinsip Good Corporate Governance Dengan Kinerja Pegawai Di Dinas Kesehatan Kabupaten Wajo

Arikunto,S. 2007, Prosedur Penelitian Suatu Pendekatan Praktek, PT. Bina Aksara, Jakarta, Indonesia

Bangun, Wilson. 2012, Manajemen Sumber Daya Manusia, Erlangga, Jakarta, Indonesia.

Bastian, Indra. 2014, Sistem Pengendalian Manajemen. Jakarta: Salemba Empat

Belkhir, Mohamed, 2005, „,Board Structure, Ownership Structure and Firm Performance:Evidence From Banking, Laboratotare Economic di Orleans available at: http:// ssrn.com
Buchari Zainun, 2006, Manajemen dan Motivasi, Balai Aksara, Jakarta, Indonesia

Budiharta, Pratiwi \& Gusnadi, (2008), Analisis Pengaruh Karakteristik Perusahaan dan Penerapan Good Corporate Governance Terhadap Tindakan Perataan Laba Yang Dilakukan Oleh Perusahaan Yang Terdaftar di Bursa Efek Jakarta. Jurnal Ekonomi dan Bisnis 20 (September): 126-138.

Daniri, Ahmad, 2005, „GCG: Konsep dan Pnerapannya dalam Konteks Indonesia

Darmawansyah dkk. 2013, „Penerapan Prinsip- prinsip Good Corporate Governance Terhadap Kepuasan Kerja dan Kinerja Karyawan. Jurnal AKK Indonesia, Vol 2 No2, Mei 2013, hal 19.

Deikme, Pilatus. 2013, Motivasi Kerja dan Budaya Organisasi Pengaruhnya Terhadap Kinerja Pegawai Bagian Keuangan Seda Mimika Provinsi Papua, Jurnal EMBA. Vol.1, No.3, Juni 2013, Hal. 980 -986. ISSN 2303

Dessler, Gerry, 2006, Manajemen Personalia, Edisi 3 (terjemahan Agus Dharma), Erlangga Jakarta, Jakarta, Indonesia

Fauziyah sifa. 2016, Analisis Pengaruh Penerapan Prinsip-Prinsip Good Corporate Governance, Motivasi Dan Budaya Organisasi Terhadap Kinerja 
Aparatur Pemerintahan, Jurnal Universitas Muhamadiyah, Surakarta.

Sedarmayanti. 2014, Governance dan Good Corporate Governance. Edisi ketiga, Mandar Maju, Bandung, Indonesia.

Sutedi, Adrian. 2013, Good Corporate Governance, Gramedia, Jakarta, Indonesia.
Sugiyono. 2008, „Metode Peneitian Kuantittif Dan Kualitatif, Alfabeta, Bandung, Indonesia.

Soulef Zekri, 2012, „Good Corporate Governance: Observations and Recommendations for the MENA Zone; Journal of Business Studies Quarterly Vol. 4, No. 2, pp. 128-139 